\title{
INDONESIAN AND PACIFIC ISLAND PALAEOECOLOGY GAUGING THE IMPACT OF PREHISTORIC SETTLEMENT
}

\author{
Joshua Griffin \\ (Intern, Balai Arkeologi Yogyakarta)
}

\begin{abstract}
Anthropogenic optimal foraging models have provided a theoretical foundation for evaluating fluctuations in human resource use, thereby providing archaeology with a platform to present various theories on prehistoric island resource exploitation and habitat alteration. This paper cross-examines three major elements of remains found in island assemblages: those being avifauna, marine fauna, and palaeobotanical remains (from Henderson Island, American Samoa and Hawaii, and eastern Indonesia respectively). In doing so, the sequence of prehistoric resource depression or extinction should be readily identified through this anthropogenic behaviour. However, the Polynesian faunal assemblages shed more light on anthropogenic impact than the palaeobotanical record from Indonesia. Nevertheless, as a comparative study, this information provides a framework for present-day management and the potential restoration of these island ecosystems.
\end{abstract}

Keywords: Prehistoric resource exploitation, habitat alteration, Polynesia, Indonesia

\section{PALEOEKOLOGI INDONESIA DAN KEPULAUAN PASIFIK: MENGUKUR DAMPAK DARI PERMUKIMAN PRASEJARAH}

\begin{abstract}
ABSTRAK
Model-model antropogenik mencari makan secara optimal telah menyediakan sebuah landasan teori untuk mengevaluasi gejolak penggunaan sumberdaya manusia. Model tersebut diharapkan akan melengkapi teori arkeologi melalui sebuah bagan yang menampilkan berbagai teori tentang sumber daya pulau masa prasejarah dan perubahan habitat. Makalah ini membahas tiga hal utama pada temuan tinggalantinggalan di berbagai pulau: yaitu temuan avifauna (unggas), fauna laut, dan tinggalan-tinggalan paleobotani (dari Pulau Handerson, Samoa Amerika dan Hawaii, dan Indonesia bagian Timur). Dalam kajiannya, urutan penurunan sumber daya prasejarah atau kepunahan seharusnya diidentifikasi dengan mudah melalui perilaku antropogenik ini. Akan tetapi, kumpulan fauna Polynesia menunjukkan dampak antropogenik lebih jelas dari pada catatan paleobotani dari Indonesia. Walaupun demikian, sebagai sebuah studi
\end{abstract}


komparatif, informasi ini menyediakan kerangka kerja bagi manajemen masa kini dan pemulihan potensi ekosistem pulau ini.

Kata kunci: eksploitasi sumber daya prasejarah, perubahan habitat, Polynesia, Indonesia

\section{INTRODUCTION}

The colonisation of Polynesia and the islands of eastern Indonesia by prehistoric settlers is one of the most remarkable achievements of human history, although achieved at the detrimental expense of other life forms. Following initial colonisation, significant environmental change occurred in island southeast Asia closely followed by the Pacific. This proliferation is believed to have caused numerous faunal extinctions, including avifauna and marine species, as well as widespread deforestation (Anderson 2002; Keegan \& Diamond 1987; Spencer \& Benton 1995). By aiming to discover the sequence of anthropogenic exploitation, this paper will: (1) outline subfossil avifaunal case studies on Henderson Island, thereby highlighting the importance of distinguishing between human induced (cultural) and nonhuman induced (non-cultural) deposition, (2) summarise the degree of cultural impact on marine fauna from research compiled in American Samoa and Hawaii, (3) outline the agricultural subsistence patterns of early Indonesians, and (4) merge these cases of resource depletion to ultimately decide which groups were impacted upon more - if at all - during prehistoric colonisation.

\section{BACKGROUND}

To differentiate the results of natural perturbations from the effects of human induced changes is one of the greatest obstacles for archaeologists. But recent foraging theory models have provided a theoretical basis for scrutinising temporal shifts in resource exploitation as a result of human subsistence practices and environmentally-induced decreases in prey abundance (Morrison \& Addison 2008). Based on the conveniently definite borders of their ecosystems, islands are often viewed as "laboratories" (Keegan \& Diamond 1987:50) for the study of cultural and ecological processes. The islands of southeast Asia and the Pacific witnessed a twopart development and dispersal of populations. From the islands of southeast Asia, the early settlers gradually dispersed out into the Pacific, further developing their techniques of agriculture, arboriculture and foraging practices (Glover \& Bellwood 2004). 


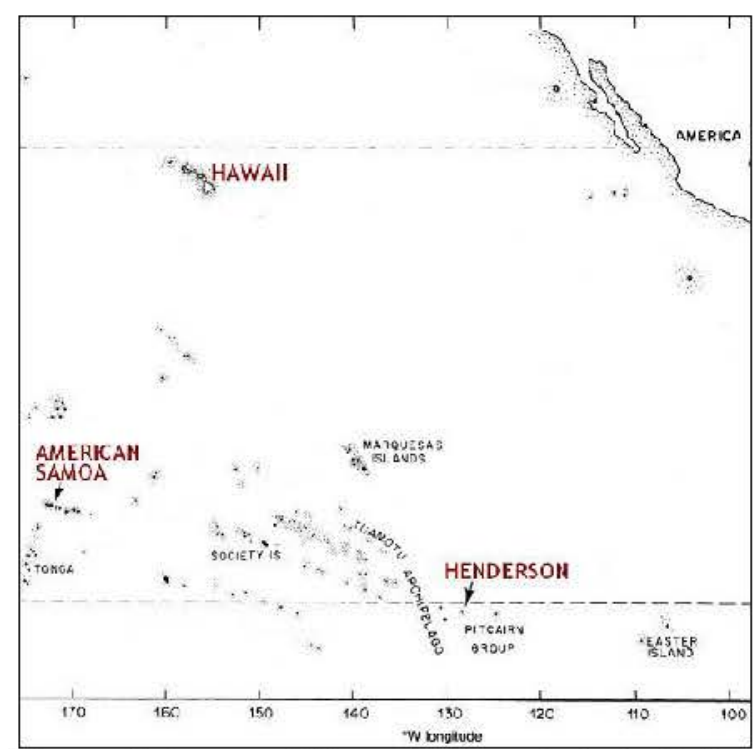

Figure 1: A map of Remote Oceania (adapted from Steadman 1986:6192).

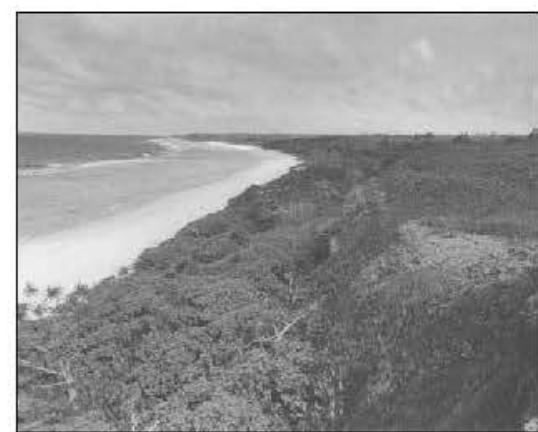

Figure 2: Topography of Henderson Island (adapted from Weisler 1998:381).

\section{HENDERSON}

Distinguishing between human influenced and non-human influenced avifaunal assemblages in the Pacific Islands is essential because it helps gauge the impact of prehistoric human colonisation, through direct (predation) and indirect human activity (foreign species introductions and habitat alteration) (Athens et al. 2002). However, avifaunal remains found in situ can be difficult to categorise. Marine taxa discovered in terrestrial assemblages are almost certainly deposited culturally, whereas bird remains are capable of being deposited by both cultural and natural means due to a bird's flying capabilities (Weisler \& Gargett 1993). Nevertheless, with a deep understanding of the two deposition types, one can ultimately classify assemblages as culturally or naturally deposited, or a combination of both.

\subsection{Henderson Island}

Part of Pitcairn in the south Pacific, Henderson Island (see Figure 1) is a raised coral limestone island surrounded by steep cliffs (Steadman \& Olson 1985; Weisler 1994, 1995; Wragg \& Weisler 1994). The rapid uplift history of the island provided only sufficient time for the formation of narrow beaches and reefs (see Figure 2). Compared with a typical continental Indonesian island, Henderson's marine diversity is minimal, with poorly developed soils supporting only a limited range of plant species, and annual rainfall only amounting to $1700 \mathrm{~mm}$ (Steadman \& Olson 1985; Weisler 1994, 
1995). Using an undergraduate research proposal on the taphonomic study of bird bones from a particular Henderson assemblage (Griffin 2008), it is possible to: (1) highlight the major differences between cultural and noncultural deposition, (2) distinguish their respective taphonomic characteristics and visibility in the archaeological record (Behrensmeyer 1978), and in doing so (3) determine whether or not Henderson colonisers were the cause of detrimental effects on avifaunal species and their environment.

\subsection{Cultural versus Non-cultural Assemblages}

The fundamental reason why humans exploit animals is to extract resources, whether it is energy from consumption or materials for tools and clothing (Lyman 1994). It is important to note assemblages in which bones exhibit both spiral and snap fractures, as this indicates that the sample mixes specimens with different taphonomic histories (O'Connor 2005). Spiral breaks resulting from breaking green bone usually reflect human activity, whereas clean 'snap' breaks indicate post-depositional disturbance (Lyman 1994; Weisler 2001). Culturally induced spiral fractures from the Henderson assemblage comprised $54 \%$ of observed breaks while snap fractures made up only $13 \%$ of the breakage pattern, suggesting major human interference (see Figure 3) (Griffin 2008).

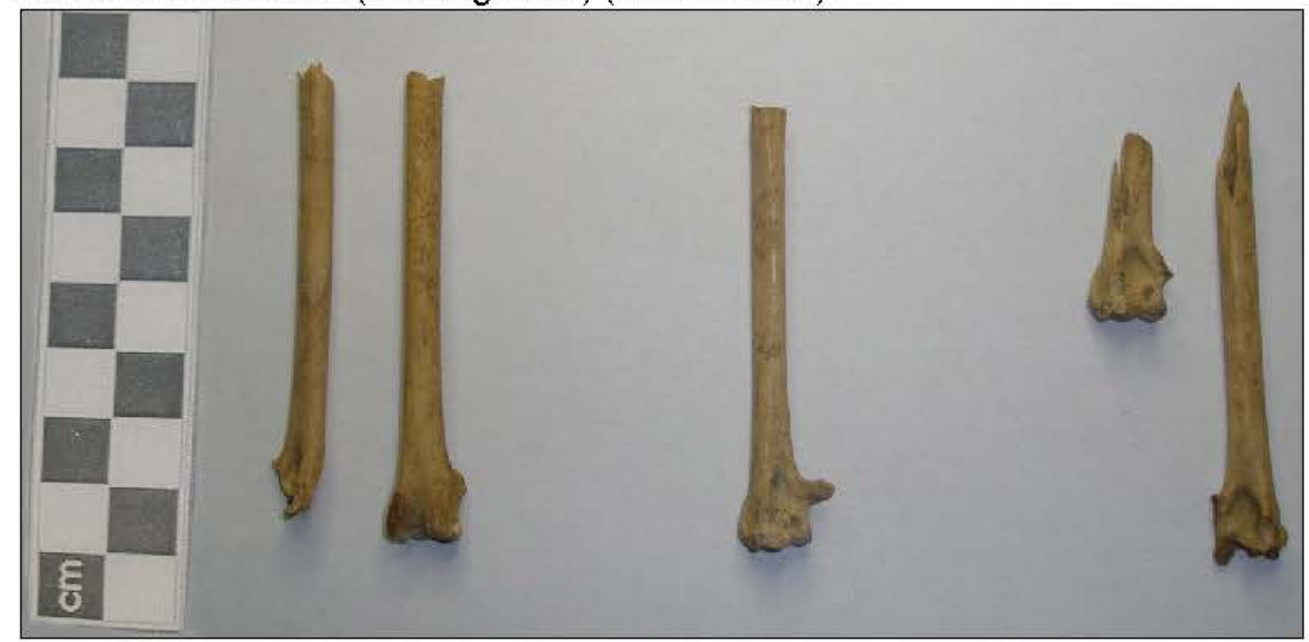

Figure 3: Three types of bone fractures in the Henderson assemblage: ragged, snap, and spiral breaks respectively (Griffin 2008).

Further evidence to differentiate human influence from natural causes can be found in bone peeling, which occurs on the articulation zones when long bones are bent during human consumption (Laroulandie 2005). Approximately $50 \%$ of long bones from Henderson exhibited peeling and well weathered extremities (Griffin 2008). Ericson's (1987) archaeozoological study showed that leg and wing bones can be highly 
over-represented in cultural contexts, while a natural cause of death seemed to have the opposite effect. The range for cultural samples stands between $30-70 \%$ of an assemblage, while non-cultural samples should be less than $30 \%$ (Ericson 1987). Only $30 \%$ of the Henderson collection consisted of limb bones (Griffin 2008). For stronger results, a broader analysis that combines various avifauna assemblages on Henderson is necessary.

\section{POLYNESIA}

Evidence of anthropogenic-induced depletion of marine populations and the structure of mollusc communities in intertidal zones is virtually unmistakeable in the archaeological record (Jackson et al. 2001; Mannino \& Thomas 2002), thereby illustrating the significance of prehistoric colonisation in the Pacific. The greatest impact on marine life in Polynesia happens to occur in coastal and inshore zones (0-50m depth), and although many impacts are recent, prehistoric resource depletion and habitat alteration appear to be the beginning of the collapse of marine ecosystems in recent times (Morrison \& Hunt 2007). For example, Anderson (1981) used an optimal foraging theory for modelling prehistoric rocky shore collecting in New Zealand. The shell midden analysis showed a temporal shift from a limited range of larger species to a wider spectrum of smaller ones, reflecting over-exploitation of the larger species more so than choice against them. This furthers the premise that marine resources were essential to the beginning of prehistoric Pacific colonisation.

\section{American Samoa}

Recent excavations in American Samoa have uncovered substantial mollusc and fish assemblages in a stratified sequence covering the last 1500 years (Morrison \& Addison 2008). From the Fatu-ma-Futi shellfish assemblage in American Samoa (see Figure 1), $150 \mathrm{~kg}$ of shellfish remnants was recovered along with other remains (Morrison \& Addison 2008). Three tests of diversity were employed to assess changes in foraging efficiency: richness, evenness, and heterogeneity. The results demonstrated that exploitation of marine species was not severe on mollusc populations through time, with an overall high level of evenness characterising the assemblage (Morrison \& Addison 2008). Although the findings were not so strong as to be adequately conclusive, documenting predation and developing models that link prehistoric human movement with marine exploitation would assist future methods for building both archaeological and ecological explanations. 


\section{Hawaii}

Claassen (1986, 1998) created a standardised summary to infer over-exploitation from shell midden samples. This synopsis states that: (1) absolute abundance of preferred species will decrease through a midden deposit; (2) mean shell size will decrease through samples taken from the bottom of a midden to the top; (3) mean or modal shell size of the archaeological samples of a species will be significantly smaller than in a non-exploited population; (4) less easily procured species will increase in number up through a midden deposit; and (5) less easily processed species will increase in number (Mannino \& Thomas 2002). Applying this model to shellfish assemblages in Hawaii (Morrison \& Hunt 2007) (see Figure 1) helped ascertain the level of susceptibility of mollusc habitats to prehistoric anthropogenic exploits. According to the assemblage recovered at Nu'alolo Kai (see Figure 4), comparisons between the shoreline and coral reef habitats demonstrated that shoreline molluscs were the smallest in size - a result that mirrors Anderson (1981). Assessment of prey size alone revealed that the intertidal patch had the lowest foraging return rate of the two habitats, supplemented by stable coral reef foraging retum rates. The complete assemblage showed evidence for increased taxonomic richness in Zone A (AD 1800 - present) with 28 taxa present, while Zone B (AD 1570 1800 ) and Zone C (AD 1410 - 1570) each contained 17 taxa (Morrison \& Hunt 2007) (see Figure 5). In general, it can be concluded that inshore marine resources were highly susceptible to human overuse, though the level of human predation was not high enough to deem the resource as severely depleted.

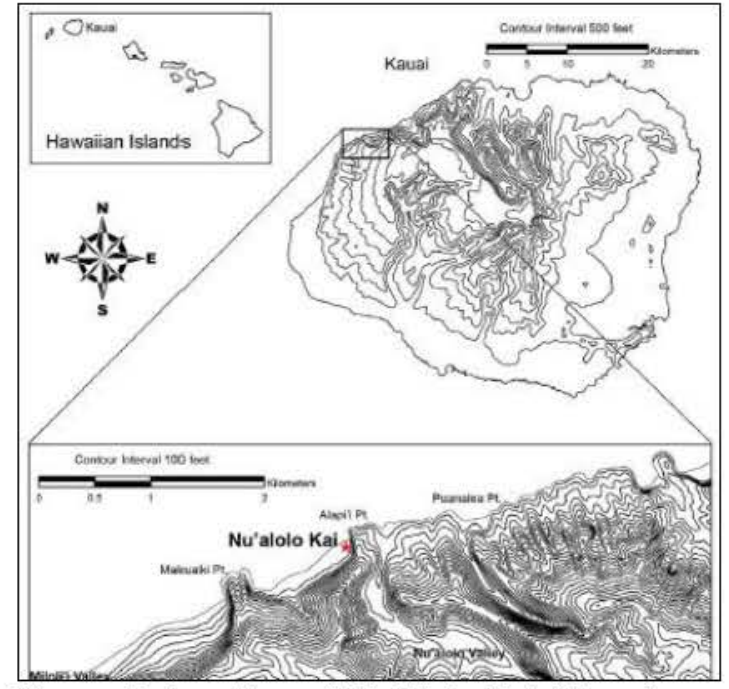

Figure 4: Location of Nu'alolo Kai (Morrison \& Humt 2007:329).

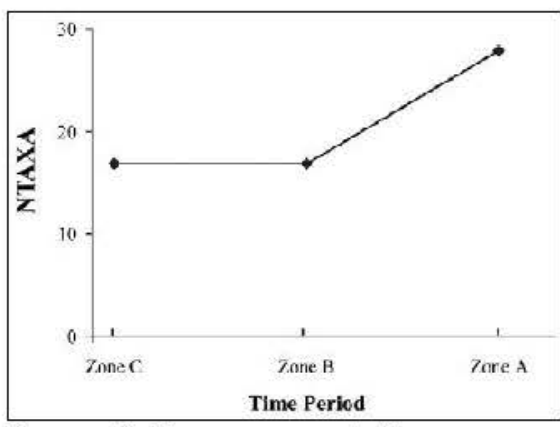

Figure B: Taxa amounts from Nu'alolo Kai assemblage (Morrison \& Hunt 2007:336). 


\section{INDONESIA}

Although the palaeobotanical record in eastern Indonesia is not as clear as some would prefer ( $\mathrm{O}^{\prime}$ Connor et al. 2005), it is evident that the origins of early Indonesians is closely associated with the cereal agriculture Taiwan Strait region. But their southward and subsequent eastward expansion demanded an ability to combine exploitation of maritime and terrestrial environments with the planting of root and arboreal crops which could be economically harvested (Bulbeck 2008). However, prior to the great Pacific migration, the candlenut (Aleunites moluccana) appears to be the plant that was more intensively and extensively exploited. The most recent excavations at Minanga Sipakko (Sulawesi) demonstrate continuous arboricultural dependence during the Neolithic. Apart from faunal remains including introduced and indigenous forest animals, as well as fish and fowl, the identified plant remains are restricted to the candlenut (Bulbeck 2008). Overall, there seems to be no visible severe resource depletion in eastern Indonesia. Nonetheless, even though much cannot be said regarding prehistoric agricultural exhaustion, contemporary villages can provide models of ancestral techniques. For example, patches of ritually interdicted forest form regular features of the complex agro-forestry system practiced among the present-day Iban of northwestern Bomeo, with swidden rice cultivation, forest management, and hunting being integral parts (Wadley \& Colfer 2004). This appears to be an appropriate and generally sustainable system.

\section{DISCUSSION}

Autocatalysis is the theory that accounts for how geography conditions culture (Keegan \& Diamond 1987), but unfortunately at this point in time, more can be said for resource depletion in Polynesia than in Indonesia. The studies throughout the Pacific have concluded that prehistoric colonisers played the largest role in the decrease of biotic diversity (Anderson 2002; Steadman 1989, 1995; Steadman \& Olson 1985; Weisler 1994, 1995; Weisler \& Gargett 1993; Wragg 1995). The collections of avifaunal remains on Henderson Island have generally been found in direct association with cultural materials (Steadman \& Olson 1985; Weisler 1995). Therefore it is arguable that the archaeological evidence shows that an abandoning of Henderson by prehistoric people occurred due to a lack of resources. Apart from the depleted avifauna, there was a low abundance marine fauna in the small and confined reefs, as well as a high degree of difficulty in growing introduced cultigens in the limited areas of arable soils. In regards to marine resource exploitation, the noticeable devastation that struck the avifauna is not as apparent. Both the studies in American Samoa (Morrison \& Addison 2008) and Hawaii (Morrison \& Hunt 2007) demonstrate that yes, humans exploited marine fauna, but exhaustion was not as severe 
as human impact was on Henderson. Concerning eastern Indonesia prehistoric colonisers, it is possible that the difficulty of identifying resource depression is due to their close proximity to mainland Asia, and the subsequent proximity to abundant quantities of rich resources. In contrast, the initial colonisers of the Pacific had nowhere to turn, having to economise and rely on what was available to them. The most probable explanation could be optimal foraging strategies: where, upon initial arrival, prehistoric colonisers found terrestrial resources more readily available and easier to obtain, thereby preying on them more often than - or even before they touched - marine resources.

\section{CONCLUSION}

Where prehistoric Indonesian subsistence practices fit is not known. There is no apparent association with Polynesia other than being the ancestral home of Pacific Islander practices, so perhaps comparing it with Pacific research was inappropriate. What is known is that a more thorough investigation on prehistoric Indonesian resource use and depression must take place - taking in habitat alteration, marine foraging, and terrestrial fauna predation - before any further claims can be inferred. However, the three Polynesian studies are able to be collated with sufficient ease. The level of predation varies quite a lot: prehistoric human exploitation of avifauna on Henderson is much more distinct than the exploitation on molluscan communities in Hawaii and American Samoa. The vulnerability of birds was seemingly greater than the marine fauna since they were relatively less difficult to capture and consequently more affected. To survive on the marginal environments they inhabited, initial colonisers of the Pacific deemed birds as the optimal source of food and energy, so it is not a question of which type of fauna was depleted the most, but the comparative timing of exploitation. In regards to contemporary management and potential restoration of island ecosystems affected by human agency, combining historical accounts with prehistoric evidence could provide a more focused framework to implement. Increasing the amount of palaeoecological, archaeological, and historical data obtained can only benefit further studies on island palaeoecology in the Pacific as well as Indonesia. 


\section{BIBLIOGRAPHY}

Anderson, A. 1981. A model of prehistoric collecting on the rocky shore. Journal of Archaeological Science 8:109-120.

2002. Faunal collapse, landscape change and settlement history in Remote Oceania. Wond Archaeology 33:375-390.

Athens, J.S. et al. 2002. Avifaunal extinctions, vegetation change, and Polynesian impacts in prehistoric Hawaili. Archaeology in Oceania 37:57-78.

Behrensmeyer, A.K. 1978. Taphonomic and ecologic information from bone weathering. Paleobiology 4:150-162.

Bulbeck, D. 2008. An integrated perspective on the Austronesian diaspora: The switch from cereal agriculture to maritime foraging in the colonisation of island southeast Asia. Australian Archaeology 67:3151.

Claassen, C. 1986. Temporal patterns in marine shellfish-species use along the Atlantic coast in the southeastern United States. Southeastern Archaeology 5:120-137.

1998. Shells. Cambridge: Cambridge University Press.

Ericson, P.G.P. 1987. Interpretations of archaeological bird remains: A taphonomic approach. Journal of Archaeological Science 14:65-75.

Glover, I. \& P. Bellwood. (eds). 2004. Southeast Asia: From prehistory to history. New York: Routledge Curzon.

Griffin, J. 2008. Avifaunal remains on Henderson /sland: The taphonomy of cultural and natural deposition, Undergraduate research proposal. University of Queensland, St Lucia.

Jackson, J.B.C. et al. 2001. Historical overfishing and the recent collapse of coastal ecosystems. Science 293:629-638.

Keegan, W.F. \& J.M. Diamond. 1987. Colonization of islands by humans: A biogeographical perspective. Advances in Archaeological Method and Theory 10:49-92.

Laroulandie, V. 2005. Anthropogenic versus non-anthropogenic bird bone assemblages: New criteria for their distinction, pp. 25-30. in T.P. O'Connor (ed). Biosphere to lithosphere: New studies in vertebrate 
taphonomy. Proceedings of the 9th Conference of the International Council for Archaeozoology, Durham, England, August 2002, Oxford: Oxbow.

Lyman, R.L. 1994. Vertebrate taphonomy. Cambridge: Cambridge University Press.

Mannino, M.A. \& K.D. Thomas. 2002. Depletion of a resource? The impact of prehistoric human foraging on intertidal mollusc communities and its significance for human settlement, mobility and dispersal. World Archaeology 33:452-474.

Morrison, A.E. \& D.J. Addison. 2008. Assessing the role of climate change and human predation on marine resources at the Fatu-ma-Futi site, Tutuila Island, American Samoa: An agent based model. Archaeology in Oceania 43:22-34.

Morrison A.E. \& T.L. Hunt. 2007. Human impacts on the nearshore environment: An archaeological case study from Kauai, Hawailan Islands. Pacific Science 61:325-345.

O'Connor, T.P. (ed). 2005. Biosphere to lithosphere: New studies in vertebrate taphonomy. Proceedings of the 9th Conference of the International Council for Archaeozoology, Durham, England, August 2002, Oxford: Oxbow.

O'Connor, S. et al. 2005. The archaeology of the Aru Islands, eastern Indonesia. Canberra: Pandanus Books/ANU E Press.

Spencer, T. \& T.G. Benton. 1995. Man's impact on the Pitcairn islands. Biological Journal of the Linnean Society 56:375-376.

Steadman, D.W. 1989. Extinction of birds in eastern Polynesia: A review of the record, and comparison with other Pacific Island groups. Journal of Archaeological Science 16:177-205.

Steadman, D.W. \& S.L. Olson. 1985. Bird remains from an archaeological site on Henderson Island, south Pacific: Man-caused extinctions on an "uninhabited" island. Proceedings of the National Academy of Sciences of the United States of America 82:6191-6195.

Wadley, R.L. \& C.J.P. Colfer. 2004. Sacred forest, hunting, and conservation in west Kalimantan, Indonesia. Human Ecology 32(3):313-338. 
Weisler, M.I. 1994. The settlement of marginal Polynesia: New evidence from Henderson Island. Journal of Field Archaeology 21:83-102.

1995. Henderson Island prehistory: Colonisation and extinction on a remote Polynesian island. Biological Journal of the Linnean Society 56:377-404.

Weisler, M.I. 2001. On the margins of sustainability: Prehistoric settlement of Utrok Atoll, northem Marshall Islands. BAR International Series 967, Oxford: Archaeopress.

Weisler, M.I. \& R.H. Gargett. 1993. Pacific island avian extinctions: The taphonomy of human predation. Archaeology in Oceania 28:85-93.

Wragg, G. 1995. The fossil birds of Henderson Island, Pitcairn Group: Natural turnover and human impact, a synopsis. Biological Journal of the Linnean Society 56:405-414.

Wragg, G. \& M.I. Weisler. 1994. Extinctions and new records of birds from Henderson Island, Pitcairn Group, south Pacific Ocean. Notornis 41:61-70. 